Closet Stages 


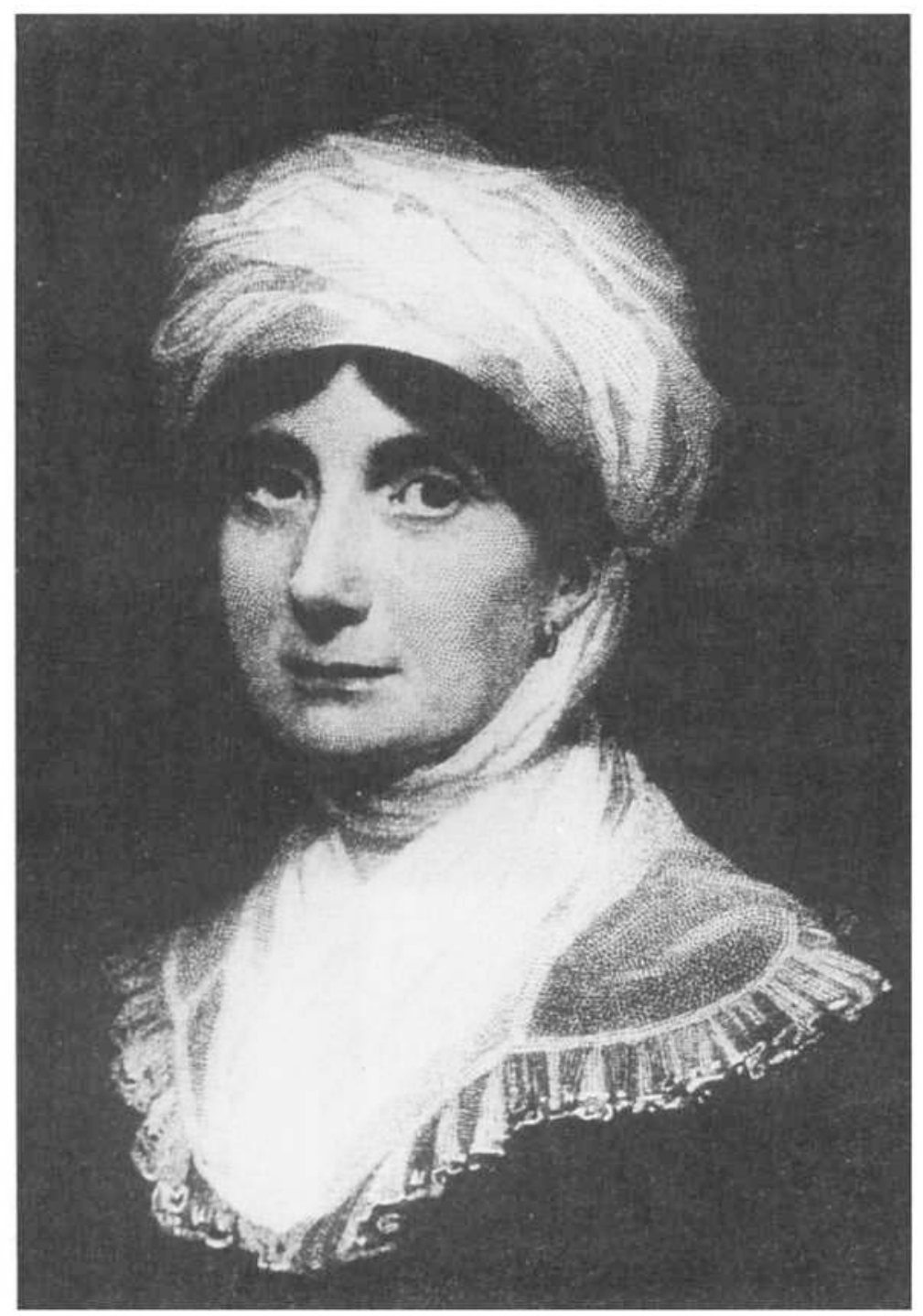




\section{Closet Stages}

\section{Joanna Baillie and the Theater Theory}

of British Romantic Women Writers

CATHERINE B. BURROUGHS

\section{$\overline{\text { PENN }}$}

University of Pennsylvania Press

Philadelphia 
Copyright (C) 1997 University of Pennsylvania Press

All rights reserved

IO 987654321

Published by

University of Pennsylvania Press

Philadelphia, Pennsylvania 19104

Library of Congress Cataloging-in-Publication Data

Burroughs, Catherine B., 1958-

Closet stages : Joanna Baillie and the theater theory of British romantic women writers / Catherine B. Burroughs.

p. $\mathrm{cm}$.

Includes bibliographical references (p. ) and index.

ISBN 0-8122-3393-X (alk. paper)

I. Baillie, Joanna, I762-I85I-Knowledge-Performing arts.

2. English drama - Women authors - History and criticism - Theory, etc.

3. English drama - Igth century - History and criticism - Theory, etc.

4. Women in the theater-Great Britain-History-19th century.

5. Romanticism-Great Britain. I. Title.

PR4056.B87 1997

$7922^{\prime} .01-\mathrm{dc2} I$

97-3949

CIP

Frontispiece: Joanna Baillie. Engraving by $\mathrm{H}$. Robinson from a miniature portrait by Sir William John Newton, in the possession of the British Museum. 
To Rick, body and soul 
This page intentionally left blank 